\title{
THE PRACTICE OF USE OF MODELS PREDICTING FINANCIAL DISTRESS IN SLOVAK COMPANIES
}

\author{
L'ubica Lesáková \\ Matej Bel University, Banská Bystrica, Slovakia \\ Petra Gundová \\ Matej Bel University, Banská Bystrica, Slovakia \\ Miroslava Vinczeová \\ Matej Bel University, Banská Bystrica, Slovakia
}

\begin{abstract}
The need to predict the danger of business bankruptcy calls for the application of models predicting financial distress. The article shows the current state in their application in Slovak companies. The aim of this paper is to present the results of the research focused on the identification of the current situation concerning the knowledge and use of models predicting financial distress in Slovak companies. There are four sub-objectives developed in the paper. Based on them, four hypotheses were formulated. Following the main aim, the paper presents the results of the empirical research based on the questionnaire survey. Data gained by the questionnaire were processed through MS Excel and the statistical analysis of the data was conducted in SPSS statistical software. The research results confirm that most Slovak companies are unfamiliar with the term "models predicting financial distress" and consequently do not apply them in their operations. The failure to use those models primarily results from their ignorance, the company size (too small company) and the use of some other own prediction methods. Companies prefer simple methods that are time saving. The main implication of our study is the recommendation to Slovak managers to implement models predicting financial distress in their managerial work and regarding them as an integral part of business financial analysis. Our research is unique in nature; there has been no similar research conducted in Slovakia so far.
\end{abstract}

Keywords: financial analysis, financial models, prediction, financial distress, Slovak companies.

DOI: http://dx.doi.org/10.15549/jeecar.v7i1.369

\section{INTRODUCTION}

The financial analysis can be defined as a set of activities designed to identify and evaluate the complex financial and economic situation of a company. A wide range of methods, techniques and financial models of the financial analysis can be found in the literature. In this 
paper, we focus on the models predicting financial distress. They are particularly important because they detect a potential future danger of a business bankruptcy in advance. Globalization, accompanied by rapid changes, has given rise to the completely new business environment (Shpak at al., 2018 and Sroka \& Szántó, 2017). The current economic conditions require market economy actors to apply the models predicting financial distress enabling them to forecast financial health in the future based on the knowledge of the past and present financial situation. A need for ongoing evaluation of the business financial situation has been increasingly emphasized. Early diagnosis of a potential corporate failure is all the more important in the current uncertain business environment. The failure of corporate entities may affect other businesses in a negative way, with consequent adverse economic as well as social impacts. There is a social burden on former employees and their families (Schönfeld et al., 2018). Large companies mean more serious impacts on the society and therefore the government tries to minimize the social cost of defaults (Eklund et al., 2018) and a negative influence on the whole economic system (Lee et al., 2011).

A substantial body of literature covers ways of predicting financial distress, whereas the concept of financial distress itself has not been sufficiently and clearly defined, especially in terms of distinguishing it from similar terms sometimes used synonymously (Alaka et al., 2018) such as crisis, insolvency, failure and in particular bankruptcy. Crisis is usually seen as a phase of an economic cycle when a company is not able to generate and enhance its value (James, 2010). Financial distress is very often one of its outcomes most likely leading to bankruptcy (Geng et al., 2015). Bankruptcy results from insolvency and is a formal destructive instrument to solve financial distress, when a company is forced out of business. Bankruptcy (sometimes referred to as failure or insolvency) occurs when a company is not able to meet its financial obligations (Antunes et al., 2017). However, a more favourable solution is based on the going concern concept when financial distress is addressed, taking account of the foreseeable firm's future (Pozzoli \& Paolone, 2017). This implies that financial distress is a much broader concept than bankruptcy as it may lead to bankruptcy (i.e. bankruptcy is only one of possible outcomes of financial distress), liquidation or significant changes in control that may limit the stream of expected rents to controlling insiders (Lee, Yeh, 2004). Generally, financial distress is thus a financial condition when a company faces financial difficulties most commonly accompanied by liquidity constraints. Since it can have fatal consequences for companies, managers should initiate remedial actions to avoid further deterioration. Models predicting financial distress can serve as a useful managerial tool in helping them mitigate risks of financial distress and take measures in a more informed way.

The aim of the paper is to present the results of the questionnaire research focused on the identification of the current situation concerning the knowledge and use of the models predicting financial distress in Slovak companies. Four research sub-objectives would facilitate the achievement of this aim. Compared to the existing research, the originality of our study lies very much in identifying the current situation in the use of models predicting financial distress in Slovak companies. The previous Slovak and foreign research mainly focused on the verification of models predicting financial distress. The question then is: Do Slovak companies use models predicting financial distress in their practice?

The remainder of the paper is organized as follows. The next section focuses on the current state of research in the area of financial models predicting financial distress. The section Methodology of the research defines the paper's aim and four sub-objectives, four hypotheses, data sample and methods used. The most important section, Results and discussion, presents and discusses the results of the questionnaire research carried out in Slovak companies. We finalize the paper by drawing several conclusions and indicate several directions for future research.

\section{THEORETICAL BACKGROUND}

The goal of models predicting financial distress is to detect potential danger of a future business bankruptcy in advance. Financial 
managers have a large range to choose from simple or more complex models to predict financial distress. Therefore, a requirement to define the importance of the use of the models predicting financial distress in financial management and managerial decision-making has been increasingly appearing in the academic research as well as business practice.

The first research dedicated to models predicting financial distress began to appear in the 30 s of the $20^{\text {th }}$ century. Studies concentrated in particular on the application of financial ratios (Horváthová \& Mokrišová, 2018). They mainly focused on comparing financial ratios between companies and identified which of them failed and which did not (Veganzones \& Séverin, 2018). The first studies focusing on predicting financial distress were those of Fitzpatrick (1932), Merwin (1942) and Ansoff (1965). The research firstly focused on the univariate ratio analysis. The works dealt with a simple analysis of financial indicators, comparing the variable values of failing and successful companies. The highly renowned work in this area was that one of Beaver published in 1966. Beaver demonstrated that financial indicators can be useful in predicting financial distress in a company. He proved that not all financial indicators (variables) have the same predictive reliability. According to Beaver (1966), two indicators best predict the future financial development, namely cash-flow/debt capital and net profit/total assets (indicator ROA). Jabeur (2017) considers that the main advantage of a one-dimensional model is simplicity as it does not require knowledge of statistics. On the other hand, one-dimensional discrimina-tion analysis models have much more disadvantages and as such, they are not applied frequently in business practice. According to Gissel et al. (2007) and Peres \& Antao (2016), Beaver's future research suggestions indicated the higher predictive ability of aggregate indicators compared to single ratios, whereby he began to develop bankruptcy prediction models. A typical representative of the multiple discriminant analysis (MDA) was Altman (1968). He developed a five-factor model applying the linear discriminant analysis. The model was originally developed for publicly traded manufacturing enterprises and later was extended to unlisted manufacturing companies (Altman, 1983) and to other models including non-manufacturing companies (Altman et al., 1977; Altman, 2013). There are many studies examining the applicability and predictive power of the Altman model. The study of Sun et al. (2014) recognized the Altman model predicting company financial distress as a successful instrument. Sulub (2014) argues that the Altman model is accurate for the failed multinational companies at predictive power of 70 per cent, and for the non-failed at predictive power of 55 per cent. According to Gavúrová et al. (2017), many subsequent studies focus on the validation and revision of the original Altman model as well as on re-recording weights of the ratios to increase its predictive power (Bod'a \& Úradníček, 2016; Deakin, 1972; Grice, Ingram, 2001; Li, Faff, 2019 etc.). In later periods, more models of the multiple discriminant analysis were developed, e.g. the Taffler model, Springate model, Fulmer model, Beerman model.

Models of the multiple discriminant analysis were also developed in the V4 economies. The family indices IN - IN95, IN99, IN01 and IN05 were introduced in the Czech Republic. In Slovakia, there are also several representatives focusing on prediction models. Chrastinová (1998) and Gurčík (2002) were the first who applied the methodology of financial health prediction in agricultural companies. Binkert (1999) and Zalai (2000) applied the multiple discriminant analysis in commercial enterprises (Klieštik et al., 2018). The best-known Polish models are the Holda (2006), Gajdka \& Stos (1996), Prusak models (2005). The Hungarian prediction models have not had a long tradition. The most well-known are the Hajdu and Virag models (Virag \& Kristof, 2005).

Even though models based on the multiple discriminant analysis have proved quite successful, they stand up to criticism (Pereira et al., 2016). According to Klieštik, Kočišová, and Mišanková (2015), the limitations of the discriminant analysis are as follows. The models take only a normal distribution of independent variables into account; consider only homogeneity of the variation-covariance matrix; assume only a linear relationship between the independent variables. To 
overcome these limitations, Ohlson (1980) introduced a logistic regression approach to predict financial distress. Logistic regression is not subject to the restriction of normality. Therefore, logit and probity models started to be used. The Ohlson's logit model (1980) was based on the sample of 105 publicly traded industrial companies that turned bankrupt during the period 1970-1976. Zmijewski (1984) was the first who employed a probity model to forecast financial distress. He used real-world samples of companies (with the lack of proportion between failed and non-failed companies) (Veganzones \& Séverin, 2018). Compared to the MDA, the logit and probity models are easier to understand since the logistic score, taking a value between 0 and 1 , is interpretable in a probabilistic way. As Kováčová et al. (2018) say, logit and probity models appear as most relevant for the future practical use. Jabeur (2017) applies the partial least squares logistic regression as a new approach. Its empirical application demonstrates good results in companies in various areas of business.

In 1990, the neural networks technique was used for the first time to predict company financial distress. Neural networks are an alternative to the discriminant analysis. They do not require in-depth mathematical and statistical knowledge and do not need any assumptions (Horváthová \& Mokrišová, 2018). According to Azayite \& Achchab (2016), artificial neural network models belong to the most popular, as they are able to learn nonlinear input-output mapping. Although they receive growing attention, their application is still very limited (Hosaka, 2019). As shown by previous empirical research (Altman, 2002; Balcaen, Ooghe, 2006; Delina, Packová, 2013; Gavúrová et al., 2017; Grice, Ingram, 2001; Grice, Dugan, 2001; Hosaka, 2019; Karas, Režnáková, 2018; Mihalovič, 2018; Niemann, Schmidt, \& Neukirchen, 2008; Wu, Gaunt, Gray, 2010), it is evident that prediction reliability of the above models significantly decreases when they are applied in different circumstances, time periods or business environment, compared to the background conditions under which they were developed. Most of them are accounting-based which reduces their ability to predict financial distress and bankruptcy reliably. Li and Faff (2019) argue that under the going-concern principle their application is limited as predictions of firm's future financial condition may be less informative when they are based on the firm's past performance. For all these reasons, the academics construct new prediction models of artificial intelligence techniques, e.g. support vector machines, Gaussian processes, genetic algorithm (Kim et al., 2019; Antunes et al., 2017; Kononiuk et al., 2017) or prediction models based on conditional trees and random forests. Particularly, decision trees have become popular mainly due to their relative simplicity and easy graphical presentation of classification rules, enabling to interpret them clearly. Grice and Dugan (2001), however, argue that it is not clear enough whether the models are specifically useful for identifying bankrupt firms, or, more generally, for identifying financially distressed firms. Forasmuch as many financially distressed companies obviously will not declare bankruptcy, we think that it is useful to know their potential danger of financial risks before a real threat of bankruptcy. Therefore, we refer to the reviewed models as to models predicting financial distress rather than to the term "bankruptcy models".

As obvious, there is a substantial and rapidly developing body of literature on the subject. However, many authors particularly focus on verification of models predicting financial distress rather than their practical application and use. In this context, our study may be seen as pioneering, especially in Slovakia, as it maps and evaluates the use of models predicting financial distress and analyses a considerably large sample of Slovak companies

\section{METHODOLOGY OF THE RESEARCH}

The main aim of the paper focuses on the identification of the current situation concerning the knowledge and use of models predicting financial distress in Slovak companies. Four research sub-objectives facilitating the achievement of this aim were formulated. The first of them is to identify whether the Slovak companies apply any of models predicting financial distress. The second sub-objective is to identify if the use of models predicting financial distress depends on the company size. The third sub-objective is to 
identify models most frequently used to predict the financial situation in Slovak companies. The fourth sub-objective is to define the main reasons explaining why Slovak companies do not use the models predicting financial distress.

Pursuant to the above main aim and subobjectives, the four hypotheses were formulated. The validity of hypotheses was verified by means of the statistical software program SPSS (based on the primary data obtained through the questionnaire research, the significance value $\alpha$ was $5 \%$, i.e. $\alpha=0.05$ ). The hypothesis $\mathrm{H} 1$ assumes that more than 50 per cent of Slovak companies (irrespective of their size) do not apply any model predicting financial distress in order to forecast their future financial situation. The exact binomial test was used to verify the hypothesis $\mathrm{H} 1$. The hypothesis $\mathrm{H} 2$ assumes the direct correlation between the company size and the use of prediction models, i.e. we assume that large companies use models predicting financial situation to a higher extent than smaller ones. The hypothesis $\mathrm{H} 2$ was verified by means of the correlation analysis. The Fisher exact test was applied in the statistical software SPSS and to measure the correlation intensity of the analyzed qualitative indicators, we used two correlation coefficients, i.e. the Pearson coefficient and Cramer coefficient. The hypothesis $\mathrm{H} 3$ assumes that the most frequently applied models in business practice are those based on the scoring methods. We verified the hypothesis $\mathrm{H} 3$ by the parametric test of the relative frequency. The same statistical test was applied to verify the hypothesis $\mathrm{H} 4$ assuming that the main reason why Slovak companies do not use the models predicting financial distress is the lack of familiarity with them.

The primary data were obtained by means of a questionnaire. The questionnaire research was conducted from June to September 2017. The questionnaire was created by means of the Google Docs application and distributed electronically to Slovak companies of all size categories (small, medium-sized and large enterprises). Both worldwide and in the Slovak Republic, small and medium-sized enterprises play a vital role in the economy and predominate over large companies (Lesáková, 2014; Stoklasová, 2018). According to data from the Statistical Office of the Slovak Republic, there were 196355 enterprises established in the Slovak Republic as of 31 December 2016. Drawing on the research results (820 respondents), we were able to evaluate the current state reflecting the application of the prediction models in Slovak companies. In accordance with the Chi-squared test results, the sample of 820 companies is representative (according to the regional representativeness $\mathrm{p}-$ value $=0,575$; according to the classification SK NACE p-value $=0,223$ ). As resulting from the goodness of fit test, we can use the results of the questionnaire research to draw general conclusions concerning all firms.

In terms of the regional classification, companies located in the Bratislava region take a major share (276 companies, i.e. 33.66 per cent). The share of companies established in the remaining Slovak regions was relatively equal (from 8.90 per cent of companies from the Banská Bystrica region to 9.88 per cent of companies from the Trenčín region). The research sample contained the most companies belonging to the wholesale and retail sector (242 companies), industry (96 companies) and construction (65 companies). In terms of the company size (according to Commission Recommendation 2003/361/) small companies have a largest share in the sample (558 companies, i.e. 68.05 per cent), 202 companies (24.63 per cent) are the medium-sized companies and 60 companies ( 7.32 per cent) are the large companies.

\section{RESULTS AND DISCUSSION}

In the first part of the questionnaire, we examined the companies knowledge of prediction models. They were required to indicate whether they had already encountered this term. In the question whether Slovak companies know the term "models predicting financial distress", more than half of respondents (59.78 per cent) declared they had never heard this term before. The second largest group of respondents (27.19 per cent, i.e. 223 companies) included companies that have already heard the term, but they do not have more detailed knowledge and information about the models. Only 13.05 per cent of respondents (107 companies) know the term 
and these companies use some of prediction models in their business practice. That means that 87 per cent (!) of all companies do not use any prediction models. These results call for the more detailed analysis. Table 1 summarizes the results relating to the knowledge and use of the models predicting financial distress in terms of the company size.

Table 1. Knowledge and use of models predicting financial distress in terms of the company size

\begin{tabular}{|l|c|c|c|c|}
\hline \multirow{2}{*}{$\begin{array}{l}\text { Knowledge and use of models predicting } \\
\text { financial distress }\end{array}$} & \multicolumn{3}{|c|}{ Type of company } & \multirow{2}{*}{ Total } \\
\cline { 2 - 4 } & small & $\begin{array}{c}\text { medium } \\
\text { size }\end{array}$ & large & \\
\hline $\begin{array}{l}\text { Know and use models predicting financial } \\
\text { distress }\end{array}$ & $\begin{array}{c}33 \\
(5.91 \%)\end{array}$ & $\begin{array}{c}50 \\
(24.75 \%)\end{array}$ & $\begin{array}{c}24 \\
(40 \%)\end{array}$ & 107 \\
\hline Know, but do not have more information & $\begin{array}{c}144 \\
(25.81 \%)\end{array}$ & $\begin{array}{c}65 \\
(32.18 \%)\end{array}$ & $\begin{array}{c}14 \\
(23.33 \%)\end{array}$ & 223 \\
\hline $\begin{array}{l}\text { Do not know models predicting financial } \\
\text { distress }\end{array}$ & $\begin{array}{c}381 \\
(68.28 \%)\end{array}$ & $\begin{array}{c}87 \\
(43.07 \%)\end{array}$ & $\begin{array}{c}22 \\
(36.67 \%)\end{array}$ & 490 \\
\hline Total & $\begin{array}{c}558 \\
(100 \%)\end{array}$ & $\begin{array}{c}202 \\
(100 \%)\end{array}$ & $\begin{array}{c}60 \\
(100 \%)\end{array}$ & 820 \\
\hline
\end{tabular}

Source: Own preparation according to the questionnaire research.

We were more interested in the size structure of companies that know and apply models predicting financial distress. The research results confirm our assumption that the models predicting financial distress are mostly used by large companies as well as that the lack of information and insufficient knowledge is apparent particularly in small companies (381 companies). The results are not surprising. The explanation can be found in the size of companies (expressed as the number of employees) and in their organizational structure. In large companies, there usually is a specialized department responsible for financial management, while in the smaller firms, all managerial tasks are often performed by one person (a firm manager or owner). When asked "what prediction models companies know", 115 respondents said they knew the quick test, 72 companies were familiar with the financial standing ratio, 68 companies knew the Altman's $\mathrm{Z}$ score and 65 companies had knowledge of the IN Index developed by the Neumaiers. Our sample does not contain any respondent with knowledge of the decision trees, random forests or neural networks.
The part examining the application of models predicting financial distress was a key part of the questionnaire. There were three possible answers to the question "whether Slovak companies currently use any models for predicting their future financial situation": yes; no; no, but we used some prediction models in the past. This was a checking question. If respondents completed the questionnaire correctly, the number of positive answers (i.e. companies using the prediction models) should account for 107 positive answers. Figure 1 presents the answers to this question. As shown in Figure 1, 107 companies (13.05 per cent of our sample) use models predicting financial distress in their practice.

The research results enable to verify the hypotheses $\mathrm{H} 1$ and $\mathrm{H} 2$. The first hypothesis assumes that more than 50 per cent of Slovak companies (irrespective of their size) do not apply models for predicting their future financial situation. To verify the hypothesis, we used the exact binomial test. The null hypothesis (H0: $\pi=0.5$ ) and the alternative hypothesis (H1: $\pi>0.5)$ were formulated. Based upon the results obtained from the binomial test, we refuse the null hypothesis ( $\mathrm{p}$-value is 
less than the significance value $\alpha(0.05))$. The results confirm our assumption formulated in the first hypothesis that more than 50 per cent of Slovak companies (irrespective their size) do not apply any model for predicting their future financial situation. Therefore, we fail to reject the hypothesis $\mathrm{H} 1$.

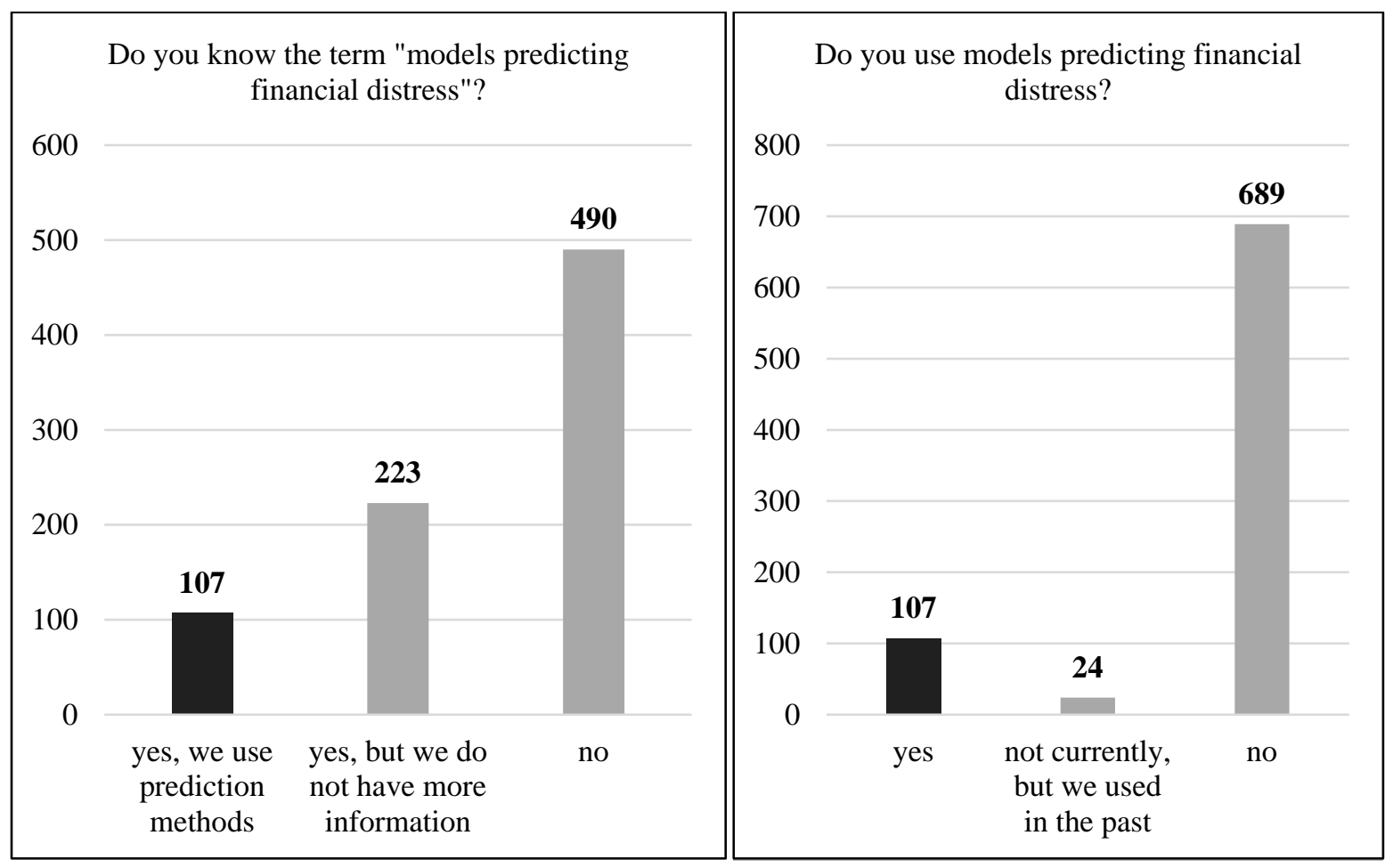

Figure 1. The use of models predicting financial distress - the comparison of the results Source: Own preparation according to the questionnaire research.

The hypothesis $\mathrm{H} 2$ assumes the existence of a direct correlation between the company size and the use of models predicting financial distress. Table 1 shows that 33 small, 50 medium-sized and 24 large companies use some of the models predicting financial distress. To verify the existence of the dependence between these two variables, we applied the Fisher exact test. In the first step, it was necessary to apply the test of independence of two qualitative variables - the Chi-squared test. Thereafter, we formulated the null hypothesis: the variables are independent; that implies that the use of the prediction models does not depend on the company size, and the alternative hypothesis: the variables are dependent, implying that the use of the prediction models depends on the company size.
Because the p-value is lower than the significance value $\alpha(0.05)$, we can reject the null hypothesis concerning the independence of two qualitative variables. That means that the use of the prediction models depends on the company size. Considering the presented results, we decided to apply the Cramer coefficient and Pearson contingency coefficient. Their values indicate the existence of the relationship between the above two variables. The Cramer coefficient value is 0.232 , implying that there is a moderate dependence between the application of the prediction models and the company size. The value of the Pearson contingency coefficient, which is 0.382 , also confirmed this result (both results reflect the moderate dependence between the application of the prediction models and the size of a company). Thus, on the basis of these results, we fail to reject the hypothesis $\mathrm{H} 2$. 
The previous question had a classification character and divided the sample into two groups. Companies that answered in the affirmative, continued the questionnaire. Companies that do not apply models predicting distress (713 companies), were automatically redirected to the final questionnaire question. They were asked to indicate main reasons why they do not use the models. The hypothesis $\mathrm{H} 4$ assumes that the main reason why Slovak companies do not use the models predicting financial distress is the lack of knowledge. All main presented reasons are summarized in Table 2. Since this was an open question, we divided the answers of 713 respondents into to six categories.

It was not surprising that more than 40 per cent of respondents indicated the lack of knowledge as the main reason of not applying the prediction methods. However, the high share of companies indicating that models predicting financial distress are not important is striking. As much as 261 companies (36.6 per cent) did not provide an answer as it was an open question. The disadvantage of this question type, i.e. reluctance of respondents to answer, proved true. To carry out the statistical evaluation of the answers, it was necessary to solve this problem (no answer available). There were two possibilities: a) to exclude these answers from further evaluation, or, b) to divide respondents without an answer analogically into the categories of the identified reasons in the same proportion as respondents who answered the question.

Table 2. Main reasons why companies do not use the models predicting financial distress (adjusted)

\begin{tabular}{|l|c|c|}
\hline $\begin{array}{l}\text { Reason why companies do not use models predicting financial } \\
\text { distress }\end{array}$ & $\begin{array}{c}\text { Number of } \\
\text { companies }\end{array}$ & $\begin{array}{c}\text { Percentage } \\
(\%)\end{array}$ \\
\hline Lack of knowledge & 298 & 41.80 \\
\hline Company size (too small company) & 120 & 16.83 \\
\hline Own prediction methods & 115 & 16.13 \\
\hline Time-consuming & 17 & 2.38 \\
\hline Models predicting financial distress are not important & 112 & 15.71 \\
\hline Management does not need models predicting financial distress & 51 & 7.15 \\
\hline Total & 713 & 100.00 \\
\hline
\end{tabular}

Source: preparation according to the questionnaire research.

To verify the hypothesis $\mathrm{H} 4$, we applied the goodness of fit test with the relative frequency expected; we suppose that the main reasons indicating why companies do not use the prediction models (the lack of knowledge or other reasons including a small company, own prediction methods, time-consuming methods, prediction models are not important, management does not need prediction models) are independent.

Since we carried out the multiple comparison, it was necessary to make the correction (we applied the Bonferroni correction; the significance value was divided in accordance with the number of tests conducted, implying the significance value was 0.05: $5=0.01$ ). In all five cases the p-value was lower than 0.01; hereby we fail to reject the hypothesis $\mathrm{H} 4$ (at the significance value $\alpha=0.05$ ). The research results show the main reasons why companies do not use the models including the lack of knowledge, company size and use of their own methods. The first two reasons are very closely linked. We can deduce that Slovak companies 
are characterized by poor knowledge of the models, often due to the lack of qualified employees. It is important that financial managers or employees who assess the company's financial condition have stronger theoretical background concerning methods of financial analysis and prediction models and are able to apply and interpret them correctly. Without the theoretical knowledge, the company cannot properly assess its financial situation and factors affecting it. In case of small enterprises, their directors often entrusted with responsibilities in other different areas, are also responsible for financial management. That is why they do not attach much importance to prediction of the financial situation and primarily focus on the assessment of the past financial situation often only on the basis of financial statements. Another group of companies (103 companies) which applies prediction models was asked to specify them.

By means of another specific question, we wanted to detect the particular models predicting financial distress used by companies. The respondents were offered various models including simple scoring methods, methods of the multiple discriminant analysis, the logistic regression and also more sophisticated methods - decision trees, random forests and neural networks. The hypothesis $\mathrm{H} 3$ assumes that the scoring methods prevail in business practice. The simplest models of assessment scoring involve the quick test and Tamari model. The questionnaire research results confirmed that most of respondents (69 respondents) used the quick test to predict their future financial health.

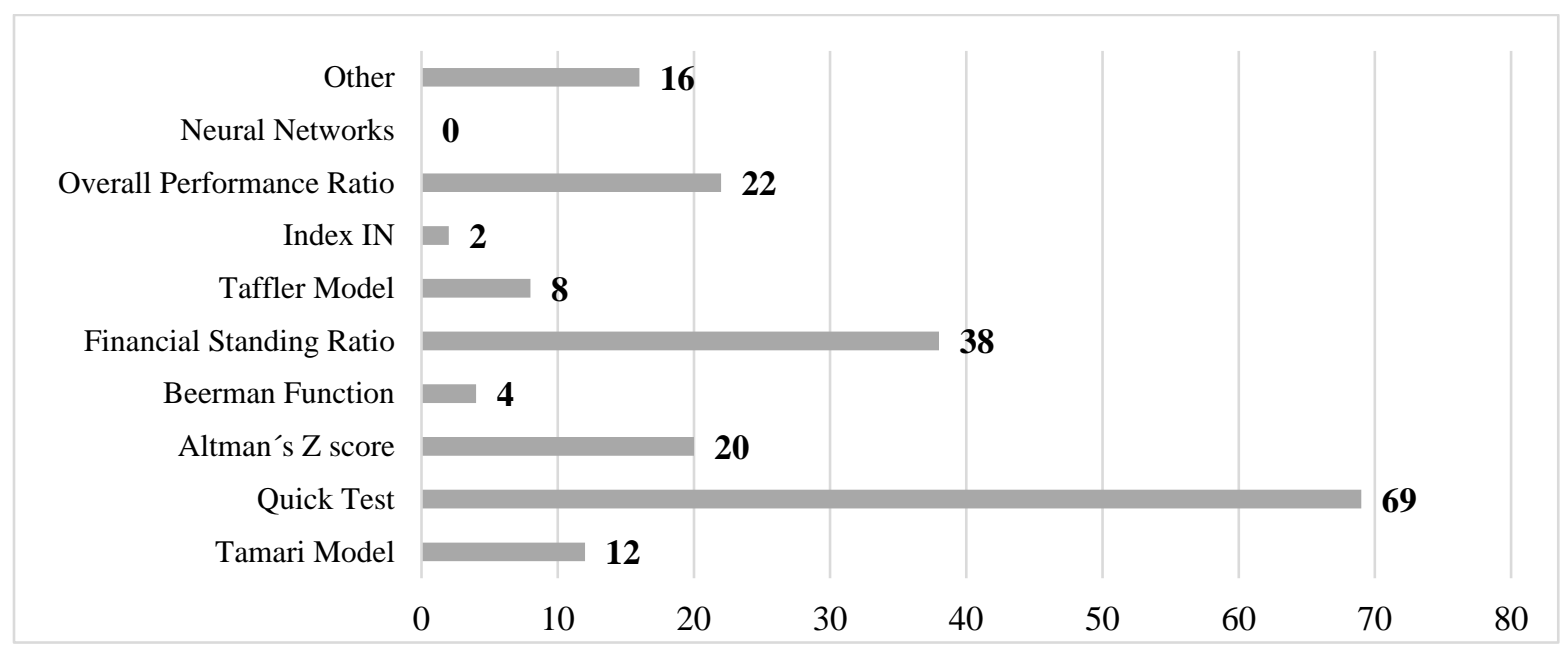

Figure 2. Prediction models used by companies.

Source: Own preparation according to the questionnaire research.

As it appears from Figure 2, Slovak companies evidently use the quick test most commonly to predict their financial situation (69 companies chose this model - they could choose from several options of prediction models). Companies indicated two main reasons for choosing the quick test: it is simple and "quick" to apply. The group containing 69 companies includes 25 small, 32 medium-sized and 12 large companies. The financial standing ratio is the second most frequently used prediction model indicated by 38 respondents. The overall performance ratio (indicated by 22 companies) appears as the third most frequently used model predicting financial distress. Only four companies (out of 16 that chose the answer "other") specified their prediction model - all these companies indicated the Zmijewski model. The fact that companies have strong preference for the quick test as an ex-ante financial analysis method results from its strengths such as simplicity, speed, time 
efficiency, and the fact that the quick test is a part of software products focused on financial analysis. As a result, small and medium-sized enterprises have increasingly been using this prediction method (there are 25 small, 32 medium-sized and 12 large companies in our research sample).

To verify the hypothesis $\mathrm{H} 3$, we applied the test of the relative frequency. The hypothesis $\mathrm{H} 3$ assumes that the share of companies using the model of the simplest assessment scoring is higher than that of companies using other financial distress prediction models. We assumed that the application of assessment scoring and that one of other models predicting financial distress were mutually independent (implying that the use of scoring models does not inform about the use of other prediction models, and vice versa). We carried out the pair comparison and, on the basis of the Chi-square test result (significance value $\alpha=0.05$ ), the hypothesis $\mathrm{H} 3$ can be confirmed. Pursuant to the statistical verification of the hypothesis $\mathrm{H} 3$, we fail to reject that the Slovak companies use mostly the methods of scoring assessment.

In the last section of the questionnaire, the respondents were required to indicate the main factors significantly influencing their choice of the models predicting financial distress. The main factors include the simplicity of methods (35 companies - 32.71 per cent), clear interpretation (32 companies - 29.90 per cent) and software support (28 companies - 29.17 per cent). The research results confirm our assumption (the hypothesis H3) as the quick test is a simple model for predicting financial distress and constitutes part of software products specifically designed for the financial analysis (i.e. Index podnikatela, Sofina, Finstat, etc.).

The research results provide a solid base for formulation of conclusions and future implications.

\section{CONCLUSION}

The need for a permanent evaluation of the financial situation of companies has been increasingly emphasized. The goal of models predicting financial distress is to detect in a timely manner factors that could endanger the very existence of a company or could even lead to its bankruptcy.

The paper presents the results of the questionnaire research focused on the identification of the current situation concerning the knowledge and use of the models predicting financial distress in Slovak companies. On the ground of the research results, we are able to evaluate the current state of the use of models predicting financial distress in Slovak companies. The term "models predicting financial distress" is not sufficiently known in Slovak companies: as much as 59.76 per cent of respondents have not heard this term before. The results of the questionnaire research confirm our assumption that large companies are better acquainted with the prediction models than the small ones. The research results show that only 13.05 per cent of respondents (107 companies) use the models predicting financial distress. Considering this, the research identified the following main reasons explaining why companies do not use the models predicting financial distress: the lack of knowledge, company size (too small company) and the use of own prediction methods. The quick test has proved to be the most frequently used prediction model in Slovak companies.

Slovak companies do not differentiate between the models predicting financial distress. They prefer to apply techniques and methods that are simple, clear to interpret and have a sufficient software support. The reason to choose a certain prediction model is linked to its construction (the number of indicators, weights, software support, etc.).

The main implication of our study is the recommendation to Slovak managers to implement models predicting financial distress in their managerial work and regarding them as an integral part of business financial analysis. This can be highly beneficial as the focus not only on past financial results but also on possible development of the future financial development is crucial when a company intends to maintain its sustainable growth and competitiveness. Even though the models predicting financial distress are used only by a small percentage of Slovak companies, attention should be given to the prediction issues. 
Companies should have an interest to extend the financial analysis to prediction methods. Understanding their importance together with the education of managers in the area of the more sophisticated prediction models should be promoted to better prepare and equip them for active tackling problems resulting from potential risks and threats endangering the future financial health of companies.

Our research provides a view of the current situation in the area of the implementation of models predicting financial distress in Slovak companies and offers a scope for improvement. In the future, we intend to focus our research on the application of models predicting financial distress differentiated according to sectors in which companies operate (industry, trade or services) and possibly extend the research to other countries. It would be interesting to repeat our primary research in other countries than Slovakia to allow for international comparisons of the use of models predicting financial distress.

\section{REFERENCES}

Alaka, H. A., Oyedele, L. O., Owolabi, H. A., Kumar, V., Ajayi, O., Akinade, O. O., Bilal, M. (2018). Systematic review of bankruptcy prediction models: Towards a framework for tool selection, Expert Systems with Applications, 94(March 2018), 164-184.

Altman, E. I. (1968). Financial ratios, discriminant analysis and the prediction of corporate bankruptcy, The Journal of Finance, 23(4), 589-609.

Altman, E. I. (1983). Corporate financial distress: a complete guide to predicting and avoiding distress and profiting from bankruptcy, $2^{\text {nd }}$ edition, New York: Wiley.

Altman, E. I. (2002). Bankruptcy, credit risk, and high yield junk bonds, Malden: Blackwell.

Altman, E. I. (2013). Predicting inancial distress of companies: revisiting the $Z$-score and ZETA @ models, Chapter 17 in A. R. Bell, C. Brooks, M. Prokopczuk (Eds.). Handbook of research methods and applications in empirical inance. Glos, UK: Edward Elgar Publishing, doi: http://doi.org/10.4337/ 9780857936097
Altman, E. I. et al. (1977). ZETA ${ }^{\mathrm{TM}}$ analysis: a new model to identify bankruptcy risk of corporations, Journal of Banking and Finance, 1(1), 29-54, doi: http://doi.org/10. 1016/0378-4266(77)90017-6

Ansoff, H. I. (1965). Corporate Strategy, New York: McGraw-Hill.

Antunes, F., Ribeiro, B., Pereira, F. (2017). Probabilistic modeling and visualization for bankruptcy prediction, Applied Soft Computing, 60, 831-843.

Azayite, F. Z., Achchab, S. (2016). Hybrid Discriminant Neural Networks for bankruptcy prediction and risk scoring, Procedia Computer Science, 83, 670-674.

Balcaen, S., Ooghe, H. (2006). 35 years of studies on business failure: an overview of the classic statistical methodologies and their related problems, The British Accounting Review, 38(1), 63-93.

Beaver, W. H. (1966). Financial Ratios as Predictors of Failure. Empirical Research in Accounting, The Journal of Accounting Research, 4, 71-111.

Binkert, Ch. H. (1999). Fruher kennung von Unternehmenskrisen mit Hilfe geeigneter Methoden im deutschen und slowakischen Wurtschaftsraum, Disertation tesis.

Bod'a, M., Úradníček, V. (2016). The portability of Altman's Z-score model to predicting corporate financial distress of Slovak companies, Technological and Economic Development of Economy, 22(4), 532-553, doi:

https://doi.org/10.3846/20294913.2016.119 7165

Chrastinová, Z. (1998). Metódy hodnotenia ekonomickej bonity a predikcie finančnej situácie pol'nohospodárskych podnikov, Bratislava: VÚEPP.

Deakin, E. B. (1972). A discriminant analysis of predictors of business failure, Journal of Accounting Research, 10(1), 167-179.

Delina, R., Packová, M. (2013). Prediction bankruptcy models validation in Slovak business environment, $E+M$ Economics and Management, 16(3), 101-110.

Eklund, J., Levratto, N., Ramello, G.B. (2018). Entrepreneurship and failure: two sides of 
the same coin?, Small Business Economics, 1-10, doi: https://doi.org/10.1007/s40804017-0067-1

European Commision, (2003). Commission Recommendation 2003/361/, from https://eur-

lex.europa.eu/LexUriServ/LexUriServ.do?uri $=0 J: L: 2003: 124: 0036: 0041:$ EN:PDF

Fitzpatrick, F. (1932). A Comparison of Ratios of Successful Industrial Enterprises with Those of Failed Firm, Certified Public Accountant, $6,727-731$.

Gajdka J., Stos D. (1996). Wykorzystanie analizy dyskryminacyjnej w ocenie kondycji finansowej przedsiębiorstw, Krakow: Wydawnictwo Akademii Ekonomicznej.

Gavúrová, B. et al. (2017). Predictive potential and risks of selected bankruptcy prediction models in the Slovak business environment, Journal of Business Economics and Management, 18(6), 1156-1173, doi: https://doi.org/10.3846/16111699.2017.140 0461

Geng, R., Bose, I., Chen, X. (2015). Prediction of financial distress: An empirical study of listed Chinese companies using data mining, European Journal of Operational Research, 241(1), 236-247.

Gissel, J. L. et al. (2007). A review of bankruptcy prediction studies: 1930 to present, Journal of Financial Education, 33(winter 2007), 142.

Grice, J. S., Dugan, M. T. (2001). The limitations of bankruptcy prediction models: Some cautions for the researcher, Review of Quantitative Finance and Accounting, 17, 151-166.

Grice, J. S., Ingram, R. W. (2001). Tests of the generalizability of Altman's bankruptcy prediction model, Journal of Business Research, 54(1), 53-61.

Gurčík, L. (2002). G-index-metóda predikcie fi nančného stavu pol'nohospodárskych podnikov, Agricultural economics, 48(8), 373-378.

Holda, A. (2006). Zasada kontynuacji działalności i prognozowanie upadłości $w$ polskich realiach gospodarczych, Krakow:
Zeszyty Naukowe/Akademia Ekonomiczna w Krakowie.

Horváthová, J., Mokrišová, M. (2018). Risk of Bankruptcy, Its Determinants and Models, Risks, 6(117), 1-22.

Hosaka, T. (2019). Bankruptcy prediction using imaged financial ratios and convolutional neural networks, Expert Systems with Application, 117, 287-299.

Jabeur, S. (2017). Bankruptcy prediction using Partial Least Squares Logistic Regression, Journal of Retailing and Consumer Services, 36, 197-202.

James, H. (2010). The creation and destruction of value, Cambridge: Harvard University Press.

Karas, M., Režňáková, M. (2018). Building a bankruptcy prediction model: Could information about past development increase model accuracy? Polish Journal of Management Studies, 17(1), 116-130, doi: https://dx.doi.org/10.17512/pjms.2018.17.1. 10

Kim, K., Lee, K., Ahn, H. (2019). Predicting Corporate Financial Sustainability using Novel Business Analytics, Sustainability, 11(64), 1-17, doi: https://doi.org/10.3390/su11010064

Klieštik, T., Kočišová, K., Mišanková, M. (2015). Logit and Probit Model used for Prediction of Financial Health of Company, Procedia Economics and Finance, 23, 850-855.

Klieštik, T., Vrbka, J., Rowland, Z. (2018). Bankruptcy prediction in Visegrad group countries using multiple discriminant analysis, Equilibrium. Quarterly Journal of Economics and Economic Policy, 13(3), 569593, doi: https://doi.org/10.24136/eq.2018.028

Kononiuk, A., Sacio-Szymańska, A., Gáspár, J. (2017). How do companies envisage the future? Functional foresight approaches, Engineering Management in Production and Services, 9(4), 21-23.

Kováčová, M., Klieštik, T., Kubala, P. Valášková, K. Radišić, M., Borocki, J. (2018). Bankruptcy models: Verifying their validity as a predictor of corporate failure, Polish Journal 
of Management Studies, 18(1), 167-179, doi: https://doi.org/ 10.17512/pjms.2018.18.1.13

Lee, S. H. et al. (2011). How do bankruptcy laws affect entrepreneurship development around the world? Journal of Business Venturing, 26(5), 505-520, doi: https://doi.org/10.1016/j.jbusvent.2010.05.0 01

Lee, T. S., Yeh, Y. H. (2004). Corporate Governance and Financial Distress: evidence from Taiwan, Corporate Governance. An International Review, 12(3), 378-388.

Lesáková, L'. (2014). Small and medium enterprises in the new world of globalization, Forum Scientiae Oeconomia, 2(3), 111-122.

Li L., Faff, R. (2019). Predicting corporate bankruptcy: What matters? International Review of Economics and Finance, 62(July2019), 1-19.

Merwin, C. L. (1942). Financial Small Corporations in Five Manufactoring Industries, 1926-1936, National Bureau of Economic Research, from https://www.nber.org/books/merw42-1

Mihalovič, M. (2018). Využitie skóringových modelov pri predikcii úpadku ekonomických subjektov v Slovenskej republike, Politická ekonomie, 66(6), 689708, doi: https://doi.org/10.18267/j.polek.1226

Nieman, M., Schmidt, J. H., Neukirchen, M. (2008). Improving performance of corporate rating prediction models by reducing heterogeneity, Journal of Banking and Finance, 32, 434-446.

Ohlson, J. (1980). Financial ratios and the probabilistic prediction of bankruptcy, Journal of Accounting Research, 18(1), 109131.

Pereira, J., Basto, M., da Silva, A. (2016). The Logistic Lasso and Ridge Regression in Predicting Corporate Failure, Procedia Economics and Finance, 39, 634-641.

Peres, C., Antao, M. (2016). The use of multivariate discriminant analysis to predict corporate bankruptcy: A review, AESTIMATIO IEB Int. J. Finance, 14, 108-131, doi: https://doi.org/ 10.5605/IEB.14.6
Pozzoli, M., Paolone, F. (2017).Corporate Financial Distress, Cham: SpringerBriefs in Finance.

Prusak B. (2005). Nowoczesne metody prognozowania zagrożenia finansowego przedsiębiorstw, Warszawa: Difin.

Schönfeld J., Kuděj, M., Smrčka, L. (2018). Financial health of enterprises introducing safeguard procedure based on bankruptcy models, Journal of Business Economics and Management, 19(5), 692-705, doi: https://doi.org/10.3846/jbem.2018.7063

Shpak, N.O., Stanusiak, N.S., Hlushko, O.V., Sroka, W. (2018). Assessment of the social and labor components of industrial potential in the context of corporate social responsibility, Polish Journal of Management Studies, 17(1), 209-220, doi: http://doi.org/10.17512/pjms.2018.17.1.17

Sroka W., Szántó R. (2017). Business ethics in CEE: analysis of research results, Proceedings of the 5th International Scientific Conference "Innovation Management, Entrepreneurship and Sustainability", 942-951.

Statistical Office of the Slovak Republic, from https://slovak.statistics.sk

Stoklasová, R. (2018). Econometric Analysis of SMEs in Eurozone, Forum Scientiae Oeconomia, 6(1), 19-29.

Sulub, S. A. (2014). Testing the predictive power of Altman's revised Z'model: the case of 10 multinational companies, Research Journal of Finance and Accounting, 5(21), 174-184.

Sun, J. et al. (2014). Predicting financial distress and corporate failure: a review from the state-of-the-art definitions, modeling, sampling, and featuring approaches, Knowledge-Based Systems, 57, 41-56, doi: http://doi.org/10.1016/j.knosys.2013.12.006

Veganzones, D., Séverin, E. (2018). An investigation of bankruptcy prediction in imbalanced datasets, Decision Support Systems, 112, 111-124.

Virag, M., Kristof, T. (2005). Neural networks in bankruptcy prediction - a comparative study on the basis of the first Hungarian bankruptcy model, Acta Oeconomica, 55(4), 403-425. 
Wu, Y., Gaunt, C., Gray, S. (2010). A comparison of alternative bankruptcy prediction models, Journal of Contemporary Accounting and Economics, 6(1), 34-45.

Zalai, K. (2000). Metódy predvídania finančnej situácie podnikov (a ich uplatnenie v SR), Finančný radca, 2(14-15), 106-128.

Zmijewski, M. E. (1984). Methodological Issues Related to the Estimation of Financial Distress Prediction Models, Journal of Accounting Research, 24, 59-82.

\section{ABOUT THE AUTHORS}

L'ubica Lesáková, email: lubica.lesakova@umb.sk

Dr. Lubica Lesáková is a Professor of Business Economics and Management at the Faculty of Economics, Matej Bel University in Banska Bystrica, Slovakia. In her professional life she devotes herself to the issues of small business economics and management, business financial analysis, business planning and innovation management.

Dr. Petra Gundová is a lecturer at the Faculty of Economics, Matej Bel University in Banská Bystrica, Slovakia. In her scientific research, she focuses on issues of the financial analysis, especially ex-ante financial analysis and its methods of prediction.

Dr. Miroslava Vinczeová is an Assistant Professor at the Faculty of Economics, Matej Bel University in Banská Bystrica, Slovakia. In the research and publishing field, she devotes herself to the support and development of small and medium-sized enterprises, their financing and financial management, innovations. 